\title{
Rethinking Nigeria's Conflicts of State Building and the Legal Imperatives Beyond Chinua Achebe's 'There Was a Country: A Personal History of Biafra'
}

\author{
Carol Ijeoma Njoku \\ University of Nigeria, Enugu Campus
}

\begin{abstract}
Among the lasting consequences of colonialism is the creation of a hybrid state structure that replaces the legacies of the precolonial indigenous social authority patterns with new western paradigms. Notwithstanding the very few exceptions in Africa, postcolonial states are besieged with conflicts some of which are ethnic-related or struggles to control power and natural resources. My paper examines the Nigerian conflicts as explored in Chinua Achebe's 'There Was a Country: A Personal History of Biafra' (2012). The analytical work examines the uncomfortable relationship that exists between the state and the sub-nationalities and how these undermine the politics of state building and the socioeconomic development in Nigeria. It further examines the intersection between political and economic conflicts and how these impact on the construction of law and power paradigm. Although Achebe's narrative is very in-depth in the analysis of Nigerian colonial and postcolonial problems, it does not reflect on the challenges of over-centralization and effects on state building. My work explores this gap to show how Nigeria's highly centralized state structure subverts all efforts to achieve true democracy and encourages dictatorship. I argue that the practice of true federalism or confederated state structure would restore autonomy of the states and sub-nationalities. Hence, the restoration of sub-national autonomy will create healthier cooperation among Nigeria's fragmented ethnic sub-nationalities and pave way for political stability and functional democracy.
\end{abstract}

Social Evolution \& History, Vol. 17 No. 1, March 2018 160-191

(C) 2018 'Uchitel' Publishing House

DOI: $10.30884 / \mathrm{seh} / 2018.01 .09$ 


\section{INTRODUCTION}

The journey towards nationhood in Nigeria has been complex and rouged, splintered by crises of instability and dysfunctional government. As a nation created out of motley nationalities, Nigeria is one of Africa's highest populated state and richly endowed with natural resources. Regrettably, it is one of the most mismanaged, crisis-ridden and the most unstable systems on the continent. Since Nigeria's independence in 1960, it has been riddled with several crises beginning with the declaration of a state of emergency in western Nigeria in 1962, the boycott of federal election in 1963 by two southern political parties, breakdown in civil authorities and crisis of rigged election in 1965. The deteriorated situation culminated in military coups and political assassinations in 1966, leading to the anti-Igbo genocide of 1966, secession and the declaration of the sovereign state of Biafra in 1967. These deteriorated into a bloody war of thirty months that cost millions of lives (Onyeonoro 1973: 86; Ogundiya 2009: 129). The postwar Nigeria has also witnessed different dimensions of political crisis such as political, religious and ethnic crises provoked by agitation for regional/subnational autonomy and decentralization of power, saying the least.

Several explanations have been advanced to account for Nigeria's persistent political instability and unsuccessful democracy. Some are linked with the trappings of colonialism and neo-imperialism that manifest in the form of political displacement and resistance from the minority groups. For example, John P. Macintosh argues that Nigeria was not adequately and sufficiently prepared for a solid and sustainable democracy before independence (1962). Professor Ben Nwabueze traces the Nigerian political problems to colonialism, incompatibility of the multi-ethnic nationalities, legal and structural inadequacies (2003: 11). A. M. H. Kirk-Green blames the Nigerian state for lacking in proper federal structure (1967). C. S. Whitaker Jr. attributes Nigeria's political conflicts to the legal contradictions in the Nigerian Constitution which is lacking in the basic principles of true democracy, thus reflects a mere act of military federalism (Whitaker 1981; Eresia-Eke Agha, 2012: 83). A striking example of these contradictions is the discrepancies that exist with the fundamental objectives and directive principles of state policy, which are important aspects of the socio-economic rights but are non-justiciable (Chapter 11, Constitution of the Federal Republic of Nigeria, 1999). Whitaker and Agha's views are pertinent in my study, which examines Nigeria's overcentralized structures and the possibilities of developing functional democratic federalism relying on the 1999 Constitution. 
There are other opinions on the root causes of Nigeria's failed state projects. For example, in their evaluations of Nigeria's political history and legacies, Thomas J. Davis and Azubuike Kalu-Nwiwu attributes the challenges of Nigeria's state building to mismanagement of diversity, lack of purposeful education and consequences arising from colonial legacies (2001: 3). The findings and opinions of these scholars on Nigeria's defective political structures and inadequate legal framework are very imperative to my discussion but do not in totality feed the analytic thrust of this study. Thus, a theoretical investigation is necessary to explore the cause, effects and possible remedies to the Nigerian political problems.

Some political scientists have attempted to diagnose the problems of state building by dissecting the Nigerian authority pattern, power constituents and delivery. For example, J. O. Akin-tunde relates Nigerian instability to the lack of strong democratic federal structures (1967). Building on Akin-tunde, J. Isawa Elaigwu investigates the causes of unsuccessful federalism, emerged with the conclusion that Nigeria's overly centralization of power is a major factor that undermines its democracy and projects of state building. However, he expressed pessimism towards the possibilities of Nigeria's (con)federalism (Elaigwu 2002). This study subverts Elaigwu's stance on the slim potentials of Nigeria's confederation. The fundamental gap in his work forms a critical point of analysis in this paper.

The analysis of Nigeria's political instability through deconstruction of the cultural society and its diverse authority patterns forms a major theme in E. C. Ejiogu's The Roots of Political Instability in Nigeria. Following the trajectory of postcolonial scholars, Ejiogu traces the problem beyond Nigeria's post-independent period to colonialism. But distinguishing himself from his predecessor, he explores the political power pattern in the pre-colonial and postcolonial Nigeria, arguing that 'the root of political instability in Nigeria' spawn from colonial invasion and later translated to neocolonial issues. His work indicates that the process of state building in Nigeria has sustained a legacy of brute military force and police coercion that is detrimental to a sustainable democracy (Ejiogu 2011: 2-13). His theoretical analysis shows there is an intersection between citizen's political participation with participatory democracy. He further exemplifies how a break in the chain of participation could perpetuate conflicts and instability. He evaluates the consequences of colonial amalgamation and political restructuring of the indigenous power paradigms that destroyed the social authority patterns in Nigeria. His work links the past with the present and demonstrates how the central government's failure 
to acknowledge and incorporate the distinct groups, that is, the ethnic identities of the autonomous kingdoms and nationalities forced into Nigeria became responsible for Nigeria's failed democracy and persistent instability (Ejiogu 2011: 8-13). Ejiogu's sociological evaluations of Nigeria's politics of state building is very relevant to my work. My work will adopt Ejiogu's integrated theoretical model to show how power structures are constructed, operated and inhibited in an overly centralized society like Nigeria. Although, Ejiogu neither contemplated the consequences of centralization nor the realities of Nigeria's prolonged military dictatorship that created structures of paradoxical federalism, such as seen in the 1999 Constitution. To explore Nigeria's political problems without thorough examination of the challenges of cultural nationality and social identity, over-centralization, war and prolonged era of military dictatorship, and the recent problems of globalization in the oil market may be implicitly unrealistic.

This paper explores these critical factors through a critique of Achebe's narrativization of Nigerian political problems in his personal history. My work appraises Achebe's perspectives of the Nigerian story and deconstructs the 'silences' that is the unspoken thoughts that lie hidden at the depth of narrative. As a writer who strongly believes in the role of literature in social reformation and public enlightenment, his perception is significant in the discourse of the Nigerian conflicts and political odyssey. My study examines the strength and limitations of his narrative and digs beyond narrative discourse to instantiate other critical issues that are unaccounted in the text. This work is grouped into four parts. The first segment discusses the theoretical studies and the framework of analysis. The second part is a critique of Achebe's There Was a Country and its recreation of the Nigerian political conflicts. Part three of the work examines the Nigerian problem beyond Achebe's narrative. It identifies some pertinent factors that militate against Nigerian state building, which are unrepresented in Achebe's work. These are contextualized with the theories of state conflicts and self-determination. The last part of the paper summaries findings, makes recommendations and conclusion.

\section{THEORIZING STATE CONFLICTS: POWER CONTRACTION, RESISTANCE AND SELF-DETERMINATION}

As will be unraveled below, it is widely undisputable that power contraction and loss of autonomy are natural causes of group resistance and conflicts that may lead to self-determination and secession. Some proponents of contraction theory, Jean-Jacques E. Slotine, Wei Wang 
and Khalid El Rifai have explored the different dynamics of conflicts, instability, uncertainties and mutual perturbation that are linked to contraction of power or displacement of state autonomy (1536). Wei Wang and Jean-Jacques E. Slotine posit that resistance and group struggles arising from power contraction 'may cause big uncertainty in the entire population, so that it may take the entire population a long time to finally settle down. This means that the result can be extended directly to a more general connection between parallel unidirectional rings' (Wang and Slotine 2004: 1-9). Building on Slotine and Wang's theory, Rifai and Slotine assert that secession and selfdetermination are usually the direct consequences of loss of autonomy or nationhood (Rifai and Slotine 2006: 1538-1539). The implication is that resistance, secession and self-determination are viable mechanisms used by minority groups to demonstrate their quest for political, legal or territorial changes in society. Resistance and self-determination thus operate as strategies for freedom and sovereignty that manifest especially when minority rights or autonomy seem to be threatened or displaced by the ruling power.

The principle of self-determination has been entrenched as significant aspect of the international law. The right to self-determination is a cardinal principle in modern international law, that is binding and has authoritative interpretation under the United Nations' Charter. Article $73 \mathrm{e}$ of the United Nations Charter and Article 3 guarantee among others the right to self-determination be granted to aspiring nationalities without delay, notwithstanding 'the inadequacy of political, economic, social and educational preparedness, these should never serve as a pretext for delaying the right to self-determination and independence'. The aim is to reinforce the standard principles of Universal Declaration of Human Rights (1948 and the UN Charter to avoid any form of colonization, domination and breach of human rights principles. Articles 1 and 55 of the United Nations Charter promotes the 'principles of equal rights and self-determination of peoples' (United Nations, 1945; United Nations, 2012), while Article 1.1 of the United Nations Covenant on Civil and Political Rights (1966) and the United Nations Covenant on Economic, Social and Cultural Rights (1994) provide that 'all peoples have the right to self-determination' (United Nations, 1997; United Nations, 1976; Charlotte Mueller, 2012:286). In the same manner the 1970, United Nations General Assembly Declaration on Principles of International Law concerning Friendly Relations and Cooperation among States (hereinafter 'Friendly Relations Declaration') gives great consideration to the notion of self-determination of 
peoples (286). It states: '[e]very state has the duty to promote, through joint and separate action, realisation of the principle of equal rights and self-determination of peoples' (United Nations General Assembly, 1970: 123, 124). Although in practice, the process of realizing these fundamental rights seem ambiguous and complicated.

Harry Eckstein approaches the problems of power and minority resistance through a congruence theory. He argues that political instability is associated with socio-political incongruity. His theory posits that political (in)stability is a function of the degree to which the authority patterns of governmental and segmental units are congruent with one another and consonant within themselves. Th implication is that an authority pattern operates as 'a set of asymmetric relations among hierarchically ordered members of a social unit that involves the direction of the group' (Eckstein 1971: 105). Thus, political unity or stability is achieved when there is congruence within the political structure. A break in the chain of congruence presupposes conflicts.

Ted R. Gurr further demonstrates how the flow and influence of power among the super-ordinates and subordinates' in a society result in inequalities (Eckstein 1971: 139). In an attempt to expand this theory, Ejiogu emerged with an integrated model that combined Eckstein's congruence theory with Gurr to produce an operational module the E-G Scheme. His theory shows that in democratic systems, there are channels of participation, that are open, facilitated and people utilize them intensely and voluminously through group actions, which may be direct and indirect personal actions, etc. to influence their leaders in the direction of their affairs (Eckstein 1971: 324). What this means is that channels of participation flow smoothly where there is congruence. But in autocratic systems even when channels of participation exist, they are impeded. The implication is that citizens expose themselves to enormous risks to somehow create their own channels and embark on creative acts of participation that usually subvert the system (Ibid.). In analyzing the model, Ejiogu identifies 'Responsiveness' as the logical consequence of Participation. This presupposes reactionary measures where citizens recourse to measures to over-rule and subvert their leaders when their rights and freedom are jeopardized. Such pattern of participation by indirection becomes a viable method through which the minority or subordinate groups influence their leaders and direct the affairs of their society. Hence, responsive leaders are disposed to be influenced by them and seek out 'inputs' from them (Ejiogu 2001: 328). But in an unresponsive system, the outcome could be devastating resulting to conflicts and political 
instability. It is important to examine how the chain of political participation and responsive model flow within the Nigerian state structure.

My work seeks to contextualize the contraction theories and Ejiogu's participation theory within the Nigerian case study using Achebe's There Was a Country. In the attempt to deconstruct the author's framing of Nigeria's political conflicts, attention is given to the formation of Nigeria's political structures, the flow of its channels of participation and the proximity between loss of autonomy and how these connects to the history of secession and war. The theoretical module forms the criterion for evaluating the channels of cooperation between the central government and state/ sub-nationalities. The aim is to examine how the Nigerian history, political structures and laws contribute to its conflicts; and to explore possible remedies. In the attempt to theorize the Nigerian situations and the workings of its state apparatus, this study poses the following questions: How do power flow within the Nigerian political system? Does the flow of power sustain political congruence i.e. participatory democracy? To what extent has the center allowed or impeded power congruence - participatory power channel? What are the effects of facilitated and non-facilitated power-flow? Ejiogu talks about the enormous risks associated with impeded power-flow (autocratic system) in Nigeria; my study plunges deeper into their consequences within Nigeria's concentrated postcolonial state. In critiquing Achebe's narratives on Nigeria's politics of state building, I raised critical questions on the possibilities of congruence and how these consequences could validate Wang and Rifai's theory on secession and self-determination as the by-product of loss of autonomy or nationhood. Finally, the study recommends true federalism or confederated state structure as the possible option to restoring autonomy of the states and sub-nationalities; creating stability through functional democracy, effective laws and healthier cooperation among Nigeria's fragmented ethnic sub-nationalities.

\section{ACHEBE'S THERE WAS A COUNTRY: REHASHING THE NIGERIA'S POLITICAL CONFLICTS OF STATE BUILDING}

Just as human language functions as a representation of thought, narrative is recreation of people, society, events and history. As noted by an eminent Italian theorist and philosopher, Benedetto Croce, 'where there is no narrative there is no history,' vice versa (Croce 1951: 26; Altman 2008: 1). Achebe's There Was a Country reflects Croce's thought as a reproduction of Nigeria's journey into nationhood, per- 
ceived through the author's spectacle and reference to literatures. As a nationalist who saw Nigeria's years of cradle and its rouged journey to nationhood, Achebe feels obliged to tell his perspectives of the Nigerian story to enlighten the younger generation and reawake the consciousness of the old. The story inexorably confronts the 'contested and contentious' historical issues of colonialism, transition into neocolonialism and the anomies of military dictatorship. The narrative is reproduced into six parts. It begins with the emergence of colonial rule and its subtle political machinations that destroyed Africa's maps and reshaped the glorious kingdoms of Africa for administrative convenience. The second part recounts the colonial politics and pattern of colonial administration. The third stage of the narrative discusses political transition and end of colonialism - the earliest experiment on political godfatherism institutionalized by the colonialists (K. W. Post, 1959; Achebe 2012: 50-51). The fourth stage is the era of independence, transition into neocolonialism and military dictatorship. The fifth and the six segments recount the challenges and political upheavals that bedeviled the nascent Republic and how the situations deteriorated into war. The story connects with the bloodbath of thirty months genocidal war (1967-1970) and the aftermaths of war.

Achebe's reminiscence of the famous history Berlin Conference of 1885 - the European scramble for Africa explores the painful partitioning of Africa that culminates into colonization. The author problematizes the consequences of Europe's 'discovery' of Africa with the Igbo proverb of 'rain-beating,' 'when the rain started beating us'. The Igbo philosophy of 'rain-beating' signifies an omen or serious havoc that leaves debilitating scars on the victim(s). The devastating nature of this metaphor is illustrated in a similar Igbo proverb that says - mmiri maa onye ije mma ya aruo - translated to mean that 'when a traveler is beaten by rain he or she loses beauty and luster'. Achebe compares the consequences of colonialism with the evil omen of 'rain beating.' The comparison runs throughout the narrative to satirize colonial politics particularly as it affects the part of West Africa that became Nigeria. For example, it problematizes the colonial politics of reconstructing the ancient autonomous kingdoms and empires of Africa into new colonial map, creating '...new boundaries that did violence to Africa's ancient societies and resulted in tension-prone modern states...' (Achebe 2012: 1). To emphasize the process of the coercive reconstruction done without consultation, he states: 'Great Britain was handed the area of West Africa that would later become Nigeria, like a piece of chocolate cake at a birthday party' (1). He further cap- 
tures the consequences of the restructuring that destroyed Africa's renowned kingdoms and empires like the Oyo and Ife kingdoms once strode majestically, the incomparable Benin kingdom, the Calabar and Nri kingdom that flourished across the River Niger, East, the glorious Nok kingdom of renowned terra-cotta sculptures and the Muslim Fulani Empire of the North became fused together into the ill-fated Nigerian project (2). The textual emphasis points to the far-reaching consequences of colonialism, it states:

If the Berlin Conference sealed her fate, the amalgamation of the Southern and Northern protectorates inextricably complicated Nigeria's destiny. Animist, Muslims, and Christians alike were held together by a delicate, some say artificial lattice (2).

The passage re-instantiates the draining effects of colonialism and its mindless acts of 'social engineering that enabled colonial rule and ended up creating a dangerous legacy "that will spawn political instability and created dysfunctional pathologies among inhabitants of the parts of Niger basin that Britain carved into Nigeria project' (Ejiogu 2011: 3). It is significant to examine how the natives responded to such contraction of powers and loss of their political autonomy. Although Achebe's work is reticent about these facts, critics Paul E. Lovejoy and J. S. Hogendorn (1990) have assessed the radical responses of the indigenous people to colonialism. Examples of such actions include but not limited to the Aba Women's War of November-December, 1929; the Mahdist Revolution of 1905-6 in the Sokoto Caliphate (1990: 219); the British versus Ijebu Yoruba war of 1892 and the Aro of Eastern Igboland and the Aniocha of Western Igboland's resistance attack on the British colonizers that continued up until 1914; the rebellious attack by the deposed caliph, Atahiru I in 1903 (219). These several agitations tacitly justify the transformation of society and the minority resistance to colonialism, giving credence to the TG theoretical model. The reactionary attacks and the persistent devastating counter-attacks by the colonialists represent Achebe's concepts of rainbeating. Although judging from the contemporary events, the use of the same term appears to be more or less retrospective.

The metaphorisation of colonialism with 'rain-beating' in Achebe and Ejiogu exemplify the common characteristic of postcolonial authors that routinely blames colonialism as the entire cause of Africa's political conflicts and instability. To say this is neither to give a credit to colonial politics nor to deny its debilitating consequences. Yet, 
the same colonial administration brought some positive landmarks such as Western education, viable access roads, creation of new legal order through the police force and formal court system. They even brought in the missionaries that introduced Christian religious belief and ethics, which ended some obnoxious cultural practices found to be repugnant to natural justice equity and good conscience. There Was a Country appraises the astuteness of the colonial administration, their organized system and consolidation of power in their different colonies across the world such as in India and Australia. Achebe does not put his tongue in the cheek when he distinguishes the colonial era from the present-day politics of insecurity, sporadic killings, robbery and abduction of citizens (2012: 44). Notwithstanding the divergent views of scholars on these, my critique of Achebe's postcolonial pattern of writing enjoys the privilege of distance by adopting retrospective analysis of Nigerian politics beyond colonialism. Although colonialism had its fundamental impact on Nigeria's political problems; there are other significant issues outside this spectrum that have continuously affected the political society, which this work will unravel.

At the second stage of the narrative, Achebe tells his personal stories and encounter with colonialism, Western education, and religion. He described his era as 'A Lucky Generation' (39); certainly not to praise colonialism but to distinguish the lesser evil from the upheavals of the postcolonial African society. Born into a Christian missionary at Ogidi, Anambra State in November 16, 1930 and trained in the prestigious University of London, Achebe had a deep encounter with Western colonialism while growing up, as a student and as a civil servant under the colonial administration. But these were no greater privileges compared to opportunities of his generation 'to bear witness to two remarkable transitions -the first the aforementioned impressive economic, social, and political transformation of Nigeria into midrange country' (2012: 39). Even more than these, his generation had the privilege of inheriting 'the daunting, exhilarating' and prestigious structures and privileges left by the colonial administrators as a 'bequest' as university graduates and senior officers in the civil service. Such as the privileges to step into positions and homes left by the British member, which Achebe himself was a beneficiary (48-49), although not without its own anxieties.

Colonialism ushered in laws and statutes to suit its authority paradigm. For example, history has it that the British Colonial authority did nothing to integrate the political units in state building until after the Richard's constitution in 1946. The constitution recognized three 
regions - the Northern, Western and Eastern regions and the Colony of Lagos. However, the nationalists were dissatisfied with their level of participation which led to several constitutional reforms between 1951 and 1957. These reforms ushered in gradual process of federalization of Nigeria's unitarist colonial state (Elaigwu 2002: 74). It is important to note that the colonial resistance and agitation for decolonisation at this stage was no longer a battle of clubs and gun, but a war of intelligence and diplomacy fought by the founding fathers and renowned nationalists who were privileged to receive the Western education. Their education and homecoming were opportunity to write back, fight with their pen to reclaim the African identity, freedom and power. There Was a Country took a roll call of some of such renowned nationalists whose 'burning desire for independence' and dogged efforts hastened the march to nationhood. Such men are: Herbert Macauley - the father of Nigerian nationalism, Dr. Nnamdi Azikiwe, Chief Obafemi Awolowo, Ahmadu Bello, the Sardauna of Sokoto and Sir Tafewa Balewa (2012: 44-5). Achebe's historical narrative at this stage connects nationalists' movement for freedom with the postwar experiences, that is the aftermaths of the World War 11. Part of the important phenomenon of that period was the attainment of independence.

After the World War 1 and World War 11, self-determination became prominent international law phenomenon and was projected by President Woodrow Wilson of America as a significant principle to end the war usher new era of peace and justice. The Paris Peace Conference promoted the principle of self-determination, which was made the 'peoples' entitlement (Manela 2007: 24). How was the opportunity utilized to facilitate the independence of the colonies? Achebe's narrative provides the answer, it states:

Over time, it became clear to the colonizers that they were engaged in a losing battle. By the end of World War 11 Great Britain was financially and politically exhausted. This weakness was exploited by Mohandas Gandhi and his cohorts in India during their own struggle against colonial rule. Nigerian veterans from different theaters of war had acquired certain skills - important military expertise in organization, movement, strategy, and combat - during their service to the king. Another proficiency that came naturally to this group was the skill of protest, which was quickly absorbed by the Nigerian nationalists (48). 
The passage captures the different realms of responsiveness and political participation to dismantle colonialism. Unlike the pattern during the earliest days of anti-colonial struggles, the protest for decolonization took non-violent approaches in different society. In different parts of West African, the decolonization protests took the form of ideological battle through writing and media advocacies. For example, Dr. Azikiwe's famous newspaper - The West African Pilot and Herbert Macauley's The Daily News. These represent their tactics of political participation and tool for decolonization that were synonymous to the responsive and participation theoretical module.

The march to independence yielded extraordinary excitement and expectations among the natives, although with mix-feelings caused by cravings for power by different interest groups (40). The journey to nationhood was rough and saddled with fears and uncertainties. As the prospect of independence became glaring, Nigerian politicians withdrew into their different ethnic cocoons to mobilize their different ethnic-based competitive political parties that were already marred with suspicions, fear of domination, intense pressure, power-struggles and unhealthy political rivalries. Achebe's narrative captures the satirical atmosphere and conflicts that gulped Nigeria's foremost political parties. These parties were created along ethnic lines and ideologies to protect ethno-political interest of the members. An example of such party is the National Council of Nigerian Citizens (NCNC), founded in 1944 and headed by Dr. Nnamdi Azikiwe of the Igbo subnationality. Chief Obafemi Awolowo, an accomplished lawyer of Yoruba origin provoked by what Achebe describes as 'the fear of Igbo domination in the NCNC' tactically organized the Yoruba nationality to form the Action Group (AG) in 1952 through an amalgamation of the Egbo Oma Oduduwa, the Nigerian Produce Traders Association and a few other factions (Achebe 2012: 45). In similar strand Sir Ahmadu Bello, the Sarduna of Sokoto created the Northern People's Congress (NPC) in the late 1940s to secure the Hausa-Fulani interest against the Igbos (Ibid: 46). Achebe argues that Ahmadu Bello, the Sardauna of Sokoto's creation of the Northern People's Congress (NPC) in the late 1940s was an attempt to supplement power for the then Northern educationally disadvantaged and dearth of Westerneducated politicians, unlike their Southern counterparts. He states:

He (Ahmadu Bello) overcame this 'shortcoming' by pulling together an assortment of leaders from Islamic territories under his influence and a few Western-educated intellectuals... Aminu Kano and Tafewa Balewa, Nigeria's first 
Prime Minister. Frustrated by what he saw as 'Ahmadu Bello's limited political vision' the incomparable Amino Kano ... would leave NPC in 1950 to form the left-ofcenter political party, the Northern Elements Progressive Union (NEPU)... By midcentury, through brilliant political manoevering among the Northern ruling classes Ahmadu Bello emerged as the most powerful politician in the Northern Region, indeed in all Nigeria (Achebe 2012: 46-47).

The ideologies of these three parties - NCNC, AG and NPC - reflected mainly ethnic-based interest of the three major ethnic groups that consciously exclude or rather engulf the interest of the other hundreds of minority ethnic groups. There is no doubt that such political structure could engender resistance, conflict and even agitation for disintegration going by the theories of congruity and logical consequence of participation. The trend continued as the political parties reflect the ethnic-based congress groups that were formed later in 1999 in the agitations for sub-national autonomy such as the O'dua People's Congress declared to seek for the freedom of the Yoruba, the Arewa People's Congress seeking to protect the Northern interest and the Igbo People's Congress that was set up to protect the Igbos from violence and marginalization (Elaigwu 2002: 90). The pre-independent parties aptly represent the implicit efforts by the sub-nationalities to reclaim their lost autonomies from decades colonial rule. Such attempts to reassert their political institutions created conflicts of interest that characterize the transition into nationhood. Achebe's narrative uncovers the different forms of political polarization, which unapologetically manifests in the construction of ethnic-based political parties that made the avowed national unity to resemble a mere marriage of convenience between two incompatibles. The conflicts generated by ethnic biased politics, thus undermined the political ideologies of the parties and the prospects of building of a strong nation.

The colonial transition deepened rivalries, fears, distrust and prejudices between the sub-nationalities. History has it that in 1956, the Eastern and Western Regions respectively secured self-governing status, while the Northern region had to wait until 1959. By 1957, a political diarchy had been established in which Alhaji Abubakar Tafawa Balewa emerged as the prime minister. Nigeria attained independence in 1960, after its federal elections. The first Nigerian constitution provided for a federation, which operated as parliamentary democracy (K. W. Post, 1959: 475-486; Elaigwu 2002: 74). Achebe's There Was a Country ridicules the British influence in the independence election. Britain's 
meddling with Nigeria's independence election was described as Nigeria's first rigged election, a planned deal to transfer power to the British favoured child, the Hausa-Fulani North. He remarks:

It is now widely known that Sir James Robertson played important role in overseeing the elections (or lack therefore) at independence, throwing his weight behind Abubakar Tafewa Balewa, who has been tapped to become Nigeria's first prime Minister... Later it was discovered that a courageous English junior civil servant named Harold Smith had been selected by no other than Sir James Robertson to oversee the rigging of Nigeria's so that its compliant friends in [Northern Nigeria] would win power, dominate the country, and serve British interest after independence (Achebe 2012: 50-51).

The excerpt sarcastically captures British's painful interference with the independence election, an act that contributed in the the deformation and destruction of the foundation of Nigeria federalism at its birth. One pertinent question that comes to mind at this point is: why and what informed the interest and choice made by Great Britain? Achebe's narrative provides insight into the curiosity by this statement: '... so that its compliant friends in [Northern Nigeria] would win power, dominate the country, and serve British interest after independence...It [the British colonialist] ensures that good governance will never see the light of the and that perpetual unwholesomely divisive ethnicity will forever rob Nigeria of good leadership and progressive political vision' (Achebe 2012: 51). Achebe's response provokes the need for further investigations into the what 'the masters' interests stand for?' To this, he unapologetically states:

Initially the British resisted agitations for independence, often by handing out stiff terms for 'sedition' to the 'disturbances of the peace.' They knew the value of their colonies, and the natural resources they possessed - in Nigeria's case oil, coal, gold, tin, columbite, cocoa, palm oil, groundnuts, and rubber, as well as the immense human resources and intellectual capital. Surely Great Britain had no plans to hand all these riches over without a fight (47).

The passage goes to the root cause of the colonialism and the scramble for Africa. In the case of 'the part of West Africa that became Nigeria,' the attraction and tenacity to its huge economic and human resources are enormous. The narrative further accounts for the conse- 
quences of the British persistent interference in the transition process, when their exit became inevitable. Similarly, in The Root of Political Instability, Ejiogu reexamines other justification and effects of the British choice to displace the Igbo and Yoruba authority patterns, that were democratic, with Hausa-Fulani hegemony (Ejiogu 2011: 18). The insidious 'power racketeering' left a legacy of political turbulences that destabilized the state building after independence. It was obvious that the displaced ethnic nationalities and minority groups did not suffer in silence for long time. The trappings of power contraction and political displacement brought nagging consequences that affected the growth of the nascent democratic state.

Colonialism left a weak state structure that was incapable of coping with the complex challenges of ethnic diversities and multinational interests. The re-ascendance of liberal ideas and struggles for dominance by the leading politicians of the major sub-nationalities gave new impetus to resistance and quest for national autonomy. The tension and conflicts created by the disgusted political groups and subnationalities after independence submerged Nigeria into political crises and military coup. The situation deteriorated so much in 1965 to the extent that politics itself became dangerous and unsafe for the political gladiators and spectators, thus resulted into violent conflicts. Achebe's narrative vividly captures the anomies of the neocolonial era, which he blames on the weak structures of colonialism. He argues:

Within six years of this tragic colonial manipulation Nigeria was a cesspool of corruption and misrule. Public servants helped themselves freely to the nation's wealth. Elections were blatantly rigged. The subsequent national census was outrageously stage-managed; judges and magistrates were manipulated by politicians in power. The politicians were pawns of foreign business interests (Achebe 2012: 51).

Political scientists like J. I. Elaigwu have argued that 'the problems encountered in the operation of the federation in the first republic were related to the structural imbalance in the federation, inherited from the colonial administration' (2002: 74). In the first republic, the lopsided federal structure generated fears and suspicions among groups. For example, the Northern Region was in a position to hold the whole country to ransom, as shown by the following figures: the Northern region had 79 per cent of the country's total area as compared to the Eastern region's 8.3 per cent, the Western region's 8.5 per cent and the mid-Western region's 4.2 per cent (Ibid.: 75). The same 
findings showed that according to the 1963 census figures, the regions accounted for 53.5 per cent, 22.3 per cent, 18.4 per cent, and 4.6 per cent of the total population, respectively (Elaigwu 2002: 75). It was not surprising that in the southern part of the country, there was always the fear of domination caused by the Northern Region's large population, political tyranny and the calculated benefits of the Northern population utilize for political interest. The federal structure as it existed made it impossible for the South to control political power at the center, given the ethno-regional politics of the country (Ibid.: 7475). This is not far from the truth; although the fact remains that Nigeria's problem of lopsided federal structure became broadened with the military parody of federalism, which destroyed Nigeria's earlier unitary federalism. The military regime that came into force in 1966 through a coup d'etat established a supreme military council for its dictatorial government that controlled the other arms of government. As part of its sole autonomy, it introduced a military decree and suspended the constitution, took over the media and press and concentrated powers and all emoluments to the centre, a structure that destroyed the weak federal unitarist structure formed at independence. The first coup that overthrew Sir Alhaji Abubakar Tafewa Balewa ushered Major Aguiyi Ironsi as the Head of the Federal Military Government; but was he was shortly overthrown and murdered in a counter-coup that brought General Yakubu Gowon into power as the Head of the Federal Military Government in July of the same year. Gowon's military regime recorded greater crises and political clashes partly against the Igbo sub-nationality that culminated into ethnic cleansing, secession and war.

There Was a Country captures the political conflicts that led to a gruesome pogrom and subsequent cataclysmic bloodbath. The pogrom as described by Colin Legum of The Observer (UK) (in Achebe 2012: 82) was a revengeful attack against the Igbo natives mainly across the Northern Nigeria which left about thirty thousand civilian men, women, and children slaughtered in cold blood, maimed, violated, their houses burnt, and properties destroyed and looted (Achebe 82). The Igbo nationality felt unprotected by the Nigerian government, and grossly violated their rights to life, rights to property, freedom of existence, association and religion (Chapter 111, Constitution of Nigeria, 1960). The victims sought to device alternate channels of political participation that would restore their autonomy, citizens' rights and authority to control their own affairs through secession. Achebe emphasizes the fact that it was the Igbo's loss of autonomy, violation of 
their fundamental rights to life and freedom of existence in Nigeria pushed the Igbo nationality with other minority groups into session and the declaration of a republic - the Republic of Biafra. He horns these historical facts, stating:

On May 30, 1967, Ojukwu, citing a variety of malevolent acts directed at the mainly Igbo Easterners - such as the pogrom that claimed over thirty thousand lives; the federal government's failure to ensure the safety of the Easterners in the presence of organized genocide; and the direct incrimination of the government in the murders of its own citizens - proclaimed the independence of the Republic of Biafra from Nigeria, with the full backing of the Eastern House Constituent Assembly. By taking this action Ojukwu had committed us to full-blown war. Nigeria would never be the same again (Achebe 2012: 92).

The Biafra story of secession from Nigeria is another precedent that validates Wang and Rifai's proposition that secession and selfdetermination are direct consequences of loss of autonomy. What the author describes as 'the federal government's failure to ensure the safety of the Easterners in the presence of organized genocide' signifies a break in the chain of participation, while the Biafran secession represents 'creative acts of participation or a subversion of an impeded the system.' The duty to protect citizens' lives and properties are paramount responsibilities of a sovereign state on its citizens. The Universal Declaration of Human Rights, (UDHR), gives strong vigour and authoritative expression to human life. It defines the right to life as the entitlement of every human being. 'Everyone is entitled to life, liberty and security of the person (Article 3 of the UDHR, 1945).' In the same manner, the African Charter on Human and Peoples' Rights makes the rights to life inviolable. It states inter alia:

Human beings are inviolable. Every human being shall be entitled to respect of the person for his life and integrity of his person. No one may be arbitrarily deprived of this right (African Charter on Human Peoples' Rights, 1987).

These important bills of rights are captured in Chapter III and Section 17 of the Constitution of the Federation of Nigeria, 1960 and in today's Chapter IV of the 1999 Constitution [as amended] (Chapter III, Section 17 of the Independence Constitution; Chapter IV, Section 33 (1)). These were adopted from the universal bill of rights to preserve the 
lives, rights and dignity of every citizen at all circumstances. The abysmal violation of the rights to life and the subsequent destabilization of the quasi political congruity that connects the Eastern regional government with the center sparked off resistance leading to Biafra secession and a full-blown war.

Achebe strikingly underscores the cogency of the E-G Scheme and the secessionist theorists by attesting to the fact that loss of the autonomy, insecurity of lives and properties are the compelling circumstances that drove the Igbo and entire Eastern region into session and the declaration of their own republic. He argues: 'It was very clear and sharp. It became obvious that Nigeria did not belong us. It was now clear to many of us' (Achebe 2012: 87). The loss of national identity and security in addition to the failed negotiation - the Aburi Accord to reconstruct the impeded channel of participation - led to secession resulted into a gruesome war (Ibid.: 88). The Aburi Accord represents a major peace agreement reached between Nigeria and Eastern Region in a Peace Negotiation meeting at Aburi, Ghana. Gowon's failure to implement this agreement and his subsequent proclamation of state of emergency in the East, was perceived as a Machiavellian scheme enforced through dividing the East into additional four states to landlock the Igbos into the east central state and isolate the oil producing areas of Nigeria outside Igbo land to incite interethnic rivalry that will weaken the secessionist sentiments in the region and empower the minority groups that are attached to the oilproducing areas in the new state map (Ibid.: 91). Gowon's strategy proves unsuccessful when Biafra inexorably emerged with a unanimous support of the whole region; although the steam did not last.

Again, the outcome of the conflicts between the Federal government and the then Eastern region justifies both the secession theory and Ejiogu's E-G module. Achebe's statement: 'It became obvious that Nigeria did not belong us' further gives credence to the theoretical thrust. The E-G module analyzed two binary structures of power first, a political structure with integrative government where the segmental units are congruent with one another and with channels of participation that are open and facilitated. In contrary, the second binary is predicated upon a disconnected system, which results into incongruence and lack of participation because the channels are impeded. The Nigerian and Igbo sub-nationality described in the extant situation are identified in the second binary. It portrays the existence of a polarized government where some sub-nationalities are denied fundamental 
rights and political participation. Achebe's narrative revisits some of the controversial issues on Igbo secession and the origin of Biafra. Why and how did Biafra come into being? Was Biafra Emeka Odimegwu Ojukwu's sole initiative a consensus of the then Eastern Region. He tacitly provides these answers.

\begin{abstract}
May the twenty-sixth saw an emergency meeting of Ojukwu's special Advisory Committee of Chief and Elders in Enugu. The consensus was building across cabinet that secession was the only viable path. 'On May 27, the Consultative Assembly mandated Colonel Ojukwu to declare, at the earliest practical date, Eastern Nigeria a free sovereign and independent state by the name and title of the Republic of Biafra'. It is crucial to note that the decision of an entire people, the Igbo, Nigeria, did not come from Ojukwu alone but was informed by the desires and mandated by a body that contained some of the most distinguished Nigerians in history (Achebe 2012: 92).
\end{abstract}

Early in this study, I discussed Slotine and Rifai's experiment that established a close link between loss of autonomy or nationhood with secession or quest self-determination using precedents Kosovo, Tibet and China, Sudan and South Sudan. In the case of Biafra, their secession is premised on and even beyond loss of autonomy (power and citizenship) to political displacement that threatens their lives and civil existence. Achebe's excerpt reveals how the Nigerian government's failure to accommodate and protect the lives of the Igbo nation inevitability leads to secession and war. Biafra, therefore, comes into existence because of the Igbo Southeast quest to self-preserve. The author gives insight to this important issue. In the effort to contextualize the Nigeria-Biafra story with the existing international laws such as Articles 1 and 55 of the United Nations Charter and Article 1.1 of the United Nations Covenant on Civil and Political Rights (1966) that promotes equal rights and self-determination of peoples one is provoked with the curiosity to interrogate the rationale behind the United Nations' refusal to support Biafran secession and independence. This research investigation would certainly constitute a theme for another full paper.

Achebe's narrative expressed audacity by his ability to venture into the contentious political and international law issues. The author chooses from varieties of options particularly from critical national issues require deep retrospective and introspective reflections drawn 
from varieties of precedents to indict all those who had a stake in the Biafra war tragedy. The narrative reproduces the trajectory of the Igbo and Nigerian historical realities of deformed nationhood. In the Igbo Biafra situation, the leading Igbo families entered the war as privileged elite but, emerged from it penniless, stripped, disoriented and bitter (Adichie 2014: 93). The greatest irony was the loss of the same autonomy they fought and 'died for.'

The last chapter of the book recaptures the anguish, emotional and psychological trauma that accompanies Biafra's submission to Nigeria. The most annihilating experience include the Nigerian policy of abandoned property and the paradox of paying twenty pounds to all Biafra families, and making them forfeit whatsoever amount they had in the bank before the war. These were the ironies of Gowon's reconstruction policies that left deeper wounds on the victims and cast a spell of silence on the unresolved issues of the war till date. Achebe reechoes this period of serious agony and disenchantment of a postwar Nigeria using a poetic elegy.

\author{
After a war catches \\ desperately at passing \\ hints of normalcy like \\ vines entwining a hollow \\ twig; its famished roots \\ close on rubble and every \\ piece of broken glasses (Achebe 2012: 254).
}

Achebe's poetic memories end with the painful regrets of the Biafran story portrayed by an imagery of broken glass. Significantly, his diagnostic analysis of Nigeria's political problem ended with war and the Igbo re-submission into Nigerian sovereignty. Whereas this seemingly indicates a gap in Achebe's narrative, it however provides the tool for dissecting the postwar Igbo Nigeria that is assigned with the symbolisms of 'a hollow' 'famished roots' and 'pieces of broken glasses.' The symbolism of broken and war-ravaged Biafra society forms part of the Nigerian history and struggles to nationhood. Precedents from other post-conflict societies like Sudan, South Sudan, Somalia, Burundi, Sierra Leone and Kosovo in the former Yugoslavia have shown that when any part of a state experiences political crises it affects the entire polity directly or indirectly. The impacts of the Nigeria-Biafra war on the post-conflict Nigeria and their systemic consequences to the Nigerian state-building projects are enormous and require critical reevaluation. These additional unresolved issues are not 
fully contemplated in There Was a Country. Hence, there is need for further retrospective explorations into the Nigerian problems beyond the narratives of war and colonialism.

\section{THE POSTWAR NIGERIA: THE TRANSITION FROM MILITARY TO QUASI-DEMOCRATIC (CON)FEDERALISM}

To address Nigeria's contemporary political crises, there is need to look beyond the Biafra war to confront the metaphor of a broken nation. The postwar Nigeria was an allegorical figure of a dead nation beleaguered by recurrent military dictatorship. Historical record showed that Nigeria was ruled by the military ruled 15 January 1966 to October 1979; 31 December 1983 to 27 August 1993, and from 17 November 1993 to 29 May 1999 (Elaigwu 2002: 75). The brief period following General Ironsi's Decree No. 34 of 1966 was an exception when Nigeria was officially declared a unitary state. The remaining periods before and after the war, prior to the neo-democratic experiment of 1999 were marked by successive military regimes, which exhibited pretensions of an operative federalism. Each of these military regimes called itself "The Federal Military Government; a prototype of dictatorial administration with hierarchical structure, 'not federally pyramidal' (Elaigwu 2002: 76). The Military Head of State and Commander-in-Chief operated in dictatorial patterns and exercised the sole powers of appointment and removal of the Military Governors/Administrators of the states. The appointees were made answerable to their boss, not to the people. These were clear signs of undemocratic federalism. Subsequently, as historical events unfold, both the Military Heads of State and their governors (depending on the personality of the head of state) became autonomous heads and dictators in their own kinds while administering their polities (Elaigwu 2002: 76). The different military regimes created political structures that were excessively centralized, which thus weakened the parodied structure of federalism, more with state delimitation policies. The experiences gleaned from the Biafran secession is a contributory factor to this in the sense that the central government adopted 'statism' as a part of its political strategy to weaken the sub-nationalities and dismantle their political stronghold. The aim is to eliminate the slimmest possibility for future threat to secession or self-determination. But whether this strategy has worked in Nigeria is another question deserving evaluation and critical scrutiny.

Proponents of federalism like K. C. Wheare argues that the features of true federalism first ought to reflect 'in terms of constitutional 
law and then in terms of the political relationships' which had developed on the basis of the constitutional pro- visions (36). Within such political structure, Wheare considers the following conditions as necessary and phenomenal: 1) a sense of military insecurity and of the consequent need for common; 2) a desire to be independent of foreign powers, for which union is a defence; necessity; 3 ) a hope of economic advantage from union; 4) some previous political association; 5) geographical neighbourhood; and 6. similarity of political institutions (Wheare 1946: 37-38; Birch 1966: 22). Although scholars like Livingston have divergent stance views that 'federalism is essentially a phenomenon of social diversity rather than one of constitutional mechanics' (Livingston 1956; Birch 1966: 16), the constitution as the grundnorm should serve as the machinery that controls the structural operations of a federal state. C. J. Friedrich's description of a federation as 'a union of groups, united by one or more common objectives, but retaining their distinctive group character for other purpose' gives clarity to the fact that in Federalism union of groups that seeks to retain their identity and negotiate their interest and objectives to achieve greater development and autonomy are imperative features which the federation laws must embody (Friedrich 1964; Birch 1966: 18). To achieve these, the political system(s) and organization(s) ought to have adequate power flow i.e. decision-making that is divided between a central authority and a number of regional authorities (Birch 1966: 18). The Nigerian situation is complex and complicated, reflecting a mere proliferation of a constitutional federalism. Within the complex structure, the flow of power is often impeded, which makes resistance and conflicts almost inevitable. Neither the legislature nor the judiciary and even the executive have moved proactive course of constitutional amendment on these critical issues.

During Nigeria's political transition from the military rule to democracy in May 1999, the military hand-over of power to civilians included a transfer of a constitution reviewed and packaged under the same military regime for building a democratic federation. The implication is that the foundation of Nigeria's democracy was laid by the military and the political system has not changed, except for a renewed nomenclature with few modifications to fit into a travesty of modern democracy. It is not surprising, then, that the Nigerian federation had become excessively centralized. The nature of the military rule as Elaigwu observes was dictatorial through its military decrees meaning that 'the central or federal government could assume functions reserved for the erstwhile regions through decrees, without op- 
position from politicians' (Elaigwu 2002: 76). These were demonstrated in the use of order and decrees to ban such important institutions of state building such as education and researches in schools and tertiary institutions, and the media. For example, many matters in the concurrent list, such as university education and television stations were moved, at a point, to the exclusive list of the federal government. Within these periods, the federal military government took over the new Nigerian newspapers and television stations in some states and some tertiary institutions (Elaigwu 2002: 76). The military took deliberate actions to centralize authority. The centralization policy became an extension of the omnibus powers garnered by the military administration during the war. The postwar regime thus followed the same trajectory of centralized dictatorship that is synonymous with political anarchy. Elaigwu acknowledged this aberration, commenting on its consequences to Nigeria's centralized federalism. He states as follows:

...given the country's background of the civil war. In addition, the emergency powers acquired by the federal government during the civil war were hardly reversed. Thus, the federal government acquired powers which, because they were not reversed after the civil war, made it more powerful vis-a-vis the states (Elaigwu 2002: 76).

These in addition to the splitting of political entities into small states contributed in depleting the state autonomy, empowered the center and weakened federalism. The structures became integrated into the 1999 Constitution, which were introduced by military fiat; and were not reversed under the Nigeria's parody of democratic dispensation.

The transition from military rule to democratic federalism on May 29, 1999 emerged with greater political demands and agitations for autonomy, decentralization of power and even self-determination. These were strategic responses to the overcentralized system of government. Paradoxically, the central government, which has already become used to excessive centralized powers was enlarged with the increase from oil revenue, trade and globalization. Elaigwu reiterates these facts:

By 29 May 1999, therefore, Nigeria was a highly centralized federation in which the federal center had enormous political and economic powers, with an apparently suffocating hold on the states. It was, therefore, not surprising that various Nigerian groups called for a 'Sovereign National 
Conference (SNC)'; 'National Conference'; a 'Conference of Ethnic Nationalities'; 'Devolution of Powers'; 'Restructuring of the Federation'; and others. While some Nigerian groups called for a federation with a weak center as on January 15,1966 , others called for a conference to enable ethnic nationalities to negotiate the nature of their association in the federal polity... (There were) popular agitation for a more decentralized structure, dissatisfaction with the distribution of scarce but available resources, communal conflicts, and demands by some subnational groups for greater self-determination (Elaigwu 2002: 77).

Although the agitations for restructuring and decentralization began as early as 1966, these have yielded little or no results. Absurdly, the (mis)management and control Nigeria's huge oil market become serious challenge to its political channels of participation and continued to undermine the recent democratic dispensation. The situation manifests in corruption, lack of transparency and accountability. Achebe's narrativization of Nigeria's problem of leadership in The Trouble with Nigeria and There Was a Country; even in his novels A Man of the People and Anthills of Savannah made his works prophetic and testamentary. These narratives mirror Nigeria's political voyage as paradoxical and cataclysmic. The fact is true considering the effects of the overcentralized system of government in Nigeria coupled with the 'winner takes all' system. The situation deteriorates into new paradigm of 'demo-militarism' that destroys democratic federalism and reduces accountability in governance. Lack of accountability has inimical consequences that breed impunity, bribery and corruption, god-fatherism and mismanagement of public funds. Achebe's There Was a Country thus, speaks beyond its moment, before and after Achebe's lifetime. The reality could be gleaned from the recent quests for political restructuring and self-determination.

The recent crises of decentralization and quest for autonomy in Nigeria have given rise to several dimensions of conflicts between central and state government, central government and sub-nationalities state government and local governments. Their consequences provoked several national conferences to resolve Nigeria's federating autonomy. Among these conferences is the 1994-1995 National Conference which resolved to adopt the classical model of federalism delineated by K. C. Wheare. The Constitutional Conference Report; therefore, recommended: 
It should be true federalism with clear demarcation of powers and functions among the levels of government. In the exercise of those powers and functions assigned by the Constitution, each level of government should be autonomous (Report of the Constitutional Conference 1995: 11)

The recommendation envisages more of a confederation system as practiced in the United States, which guarantees the autonomy of each confederate. Rather than focusing on the important needs, interests, autonomy and developmental prospects of the sub-ethnic nationalities, the result of the 1995 Nigerian Constitutional Conference informed the creation of six geopolitical zones, which ironically were referred to as development zones and zones for sharing resources among Nigerian groups. The complex structures contributed to wane the prospects of true federalism. These Political Zones include: North-West, NorthCentral, North-East, South-South, South-East, and South-West. The failed expectations and utter deviation of the vision of the national conference undermined the need for building constructive federalism and legal reforms. The yawning political and constitutional gap provoke new categories of agitations for restructuring. The Southwest and Southeast zones, in particular, have urged for a Sovereign National Conference to discuss the restructuring of Nigeria to ascertain the possibilities of returning to the old regions with their accompanying autonomy. This demand was partly predicated on the attempt to resolve the Niger Delta crises and regain control of the oil resources revenue. The failure to attain these dreams along with apparent disparities in the distribution of power renews the agitations for self-determination the Movement for the Actualization of the Sovereign State of Biafra (MASSOB) and the crisis in the Niger Delta areas. The MASSOB, for example, have threatened on several occasions to re-declare the 'Republic of Biafra', as was the case on May 27, 2000 (Okoli et al. 2015: 3; 2000: 1).

Similar agitations prevail among the Northern states like Zamfara, Borno and Adamawa. For instance, in Zamfara the imposition of Sharia Laws during Obasanjo's administration ushered in new strategies of pressurizing federal autonomy. Their agitation for autonomy was described by the then President Olusegun Obasanjo as 'grossly unpatriotic and mischievous' (Elaigwu 2002: 91; The Source, 2000 in Elaigwu 2002: 91). Shortly within the same administration, the Niger Delta states emerged with similar quest for freedom and autonomy that anchored on oil crisis, management and control of the oil economy and compensatory demands from the government. The crisis lin- 
gered up until the quick intervention of late President Umaru Musa Yar' Adua that brought the amnesty as remedial policies, though yielded temporary resolution. While, the Amnesty policies were implemented during President Gooduck Jonathan's tenure, Nigeria at that time was almost torn apart by Boko Haram insurgency and crisis of state insecurity. Jonathan's administration called for another National Conference that emerged with several recommendations towards restructuring Nigerian federal structure. The resolution on constitutional issues and political restructuring recommended among others:

Nigeria shall retain a Federal system of Government.

b. The core elements of the Federation shall be as follows: a Federal (Central) Government with States as the federating units.

c. Without prejudice to States constituting the federating units, States that wish to merge may do so in accordance with the Constitution of the Federal Republic of Nigeria (as amended) provided that:

i. A two-thirds majority of all members in each of the Houses of Assembly of each of the States, in which such merger is proposed, support by resolution, the merger, and

ii. A Referendum is conducted in each of the States proposing to merge with $75 \%$ of the eligible voters in each of those States approving the merger, and The National Assembly, by resolution passed by a simple majority of membership, approves of the merger. Section 8: To facilitate the merger and demerger of States. To promote economic development, good governance, equity, peace and security in accordance with the Constitution (Resolution 6.12 Final Conference Report 2014: 705).

These resolutions and recommendations from 1994-1995 and 2014 were never implemented. The Nigerian state is enmeshed into various cataclysmic political conflicts. Nigeria since 2015 has faced new paradigms of catastrophic challenges ranging from political crisis, insecurity caused by Boko Haram and Hausa Fulani herdsmen attacks, extreme hunger caused by naira inflation and economic recession.

Within the Southeast states, the struggles for autonomy and selfdetermination have gained resurgence particularly among the Igbo South East and the Niger Delta oil producing states. The recent arrest and detention of Nnamdi Kanu, the director of UK-based radio station 'Radio Biafra' and leader of a group referred to as the 'Indigenous People of Biafra (Ipob)' sparked off greater interest and sympathy for 
the pro-Biafra course. The group is determined to actualize the independence of the territories that constituted the Biafran Republic.

Kanu was arrested in Nigeria's former capital city Lagos on October 18, 2015 and held in prolonged detention without bail - a situation that provoked serious uprising among many pro-Biafrans across Nigeria and in UK (Iaccino 2015). Nnamdi Kanu's protracted incarceration, without bail, regenerated the sympathy of pro-Biafrans and freedom fighters across the world. This coupled with the ongoing agitations in the Niger-Delta areas, the debilitating consequences of Boko Haram insurgency, and the new dimensions of ethnic and religious killings by Hausa-Fulani herdsmen across several states of the middle belt and Eastern Nigeria pose serious challenges on the Nigerian state-building projects and questions the legitimacy of its federalism.

\section{RECOMMENDATIONS AND CONCLUSION}

The findings of this research indicate that Nigeria's acclaimed federalism is a misnomer, hence lacking in legitimacy, process and delivery. These constitute serious challenges to its state building. The recurrent conflicts arising from the proliferated structures of Nigeria's overcentralized federation confirms the veracity of Ejiogu's E-G module that the central government's inability to maintain congruence with the states and sub-nationalities is responsible for its political impasse, which subverts attempts to true federalism. Ultimately, the overcentralized system of government in Nigeria is instrumental to the inequalities among super-ordinates and subordinates - central government and other sub-political units. These constitute serious risk for Nigeria's democracy; and consciously obstruct the channels to participatory democracy and political stability. The depletion of Nigeria's political units into state fragments is another contributory factor that has enhanced the highly centralized government giving room to corruption and tyranny. These will continue to pose challenges for Nigerian democracy and pave way for more serious political turbulence, if unchecked.

Achebe underscores these skewed political problems through war and colonialism and their by-product being corruption and political mediocrity. Looking beyond Achebe's narrative, this study discovers that overcentralized political system in Nigeria is largely responsible for its dysfunctionality and instability. Ultimately, there is an absolute need to transform the current Nigerian's smithereens of disorganized states to reconstruct solid and functional political federalism or confederated structures that serve the realities of its confederated states in 
the twenty-first century. To achieve this, a constitutional reform is highly recommended to change the legal framework from the centralized structures of 'Military Federalism' to true federalism or confederal constitution.

Nigeria of today should look beyond the prejudices of war, ethnic hatred, and the complexes of colonialism and its hegemonic destructions to combat the present day political corruption and tyranny. These are achievable if the government could set up effective laws and structures of power that can restore its national lost glories and autonomy of the sub-nationalities. Building a functional federation or confederate across national autonomy is a fundamental approach to institutionalizing active participatory system of government - a government that would monitor and hold accountable those in charge of power, state treasury, state laws and their enforcement and judicial agents. A functional modern state exists where there are functional legal and political apparatuses that operate without coercion. Such institutions determine how the state can involve negotiation with its units without gun or prison bars and strive to safeguard the rights and liberties of all citizens without prejudice or discrimination. An ideal federal state in Nigeria would reflect the fundamental standard of its bill of rights (Constitution of the Federal Republic of Nigeria, 1999); the African Charter (1981); the Universal Declaration of Human Rights (1948) and give autonomy to the federating units. The respect for human rights and dignity as prerequisites to building a stable civil and democratic state. Achebe's narrative of the Igbo Biafra story reminds us about the danger of power displacement and state's neglect of its obligations towards security, citizens' rights and properties. The legacy of conflict and continuing atmosphere of fear and insecurity in the present-day Nigeria can be confronted through critical attention to empowering states and sub-nationalities to develop their homegrown security agents, create strong and cohesive reintegration process.

The struggles towards self-determination and autonomy by different ethnic groups in Nigeria have gathered serious momentum for more than a decade. These political agitations have taken a new face since 2015. The examples from Sudan and South Sudan, Rwanda, Burundi, the former Yugoslavia and even Syria stand out to caution Nigerians not neglect such political agitations particularly as they affect a sub-national interest for freedom. In as much as the journey towards self-determination may be far-fetched, requiring more years of political evolution; federation or confederated democracy remains Nigeria's most viable solution to its immediate political crises. A true 
federalism or confederation will streamline Nigeria's centralized authority to assign powers to the state or provincial governments. In confederation, for example, the states will retain their powers of independent nation, such as the right to maintain a military force, print money, and make treaties with other national powers. The United States began its nationhood as a confederate state, under the Articles of confederation before it amended its constitution a federal democratic system (The Articles of Confederation 1777). Also, in the United States' Federalism, the states enjoy autonomy, make their own laws, control their resources and security. With Nigeria's large population and multi-ethnic nationalities, only a federalism or confederated system of government will address the political needs of the citizens in each state, sustain 'the chain of congruity,' and make political tyranny almost impossible. The legitimate involvement of all Nigerians in creating true federalism or confederation will certainly diminish threats posed by arbitrary power and factional conflicts and consolidate foundational stability and legitimacy. Therefore, as Nigeria continues to limp along pathological conflicts, endemic corruption and political instability, the viable option to its stability is a resolution to embrace true federalism or confederation. This will restore authority and legitimacy to the nationalities to control and manage their own affairs irrespective of their size and population. The road to Nigeria's functional federalism or confederated system may seem bleak due to deep-seated convoluted interest of politicians, but that road remains the conceivable route towards political stability and constitutional freedom.

\section{REFERENCES}

Achebe, C. 2012. There Was a Country: A Personal History of Biafra. New York: Penguin Press.

Adichie, C. N. 2014. Chinua Achebe at 82: We Remember Differently. In Ayebia, N., and Currey, V. (eds.), Chinua Achebe: Tributes and Reflection (pp. 92-96). Banbury, UK: Ayebia Clarke Publishing Limited.

African (Banjul) Charter on Human and Peoples' Rights. 1981. URL: http://www.achpr.org/instruments/achpr/. Accessed February 13, 2017.

Altman, R. 2008. A Theory of Narrative. New York: Columbia University Press.

Akintunde, J. O. 1967. The Demise of Democracy in the First Republic of Nigeria: A Causal Analysis. Journal of African Studies of the University of Ife 4 (1): 3-38.

Birch, A. H. 1966 Approaches to The Study of Federalism. Political Studies XIV (1): 15-33.

The Articles of Confederation. 1777. The First Constitution of the United States). Articles of Declaration and Perpetual Union between the States of 
New Hampshire, Massachusetts Bay, Rhode Island, and Providence Plantations, Connecticut, New York, New Jersey, North Carolina, South. URL: https://www.loc.gov/rr/program/bib/ourdocs/articles.html. Accessed September 14, 2016.

Coleman, J. 1958. Nigeria: A Background to Nationalism. Berkeley: University of California Press.

Constitution of the Federal Republic of Nigeria, 1999 [Amended]. URL: http://www.nigeria-law.org/ConstitutionOfTheFederalRepublicOfNigeria. htm. Accessed October 12, 2016.

Croce, B. 1951. La storia ridotta sotto il concetto generale dell'arte. In Primi Saggi (pp. 3-41). Laterza: Bari.

Davis, T. J. and Kalu-Nwiwu, A. 2001. Education, Ethnicity and National Integration in the History of Nigeria: Continuing Problems of Africa's Colonial Legacy. The Journal of Negro History 86 (1): 1-11.

Eckstein, H. 1971. The Evaluation of Political Performance: Problems and Dimensions. Beverly Hills: Sage Publications.

Ejiogu, E. C. 2001. The Roots of Political Instability in an Artificial 'NationState': The Case of Nigeria. International Journal of Comparative Sociology 62 (3): 323-349.

Ejiogu, E. C. 2011. The Roots of Political Instability in Nigeria: Political Evolution and Development in the Niger Basin. Burlington: Ashgate.

Elaigwu, J. I. 2002. Federalism in Nigeria's New Democratic Polity Source. Publius: The Global Review of Federalism 32 (2): 73-95. URL: http://www.Jstor.Org/Stable/3330946. Accessed November 1, 2016.

Friedrich, C. J. 1964. New Tendencies in Federal Theory and Practice. In Plischke, E. (ed.), Systems of Integrating the International Community (p. 198). Princeton: D. Van Nostrand.

Iaccino, L. 2015. Nigeria: Five Things to know about Detained Biafran Leader Nnamdi Kanu. International Business Times. URL: http://www.ibti mes.co.uk/nigeria-five-things-know-about-detained-biafran-leader-nnam di-kanu-1529753. Accessed February 15, 2017.

Kirk-Green, A. M. H. 1967. Crisis and Conflict in Nigeria. London: Oxford University Press.

Livingston, W. S. 1974. Federalism and Constitutional Change. CA: Praeger Publishers.

Lovejoy, P. E., and Hogendorn, J. S. 1990. Revolutionary Mahdism and Resistance to Colonial Rule in the Sokoto Caliphate, 1905-6. The Journal of African History 31 (2): 217-244. URL: http://www.jstor.org/stable/182 766. Accessed October 28, 2010.

Macintosh, P. J. 1962. Federalism in Nigeria. Political Studies 10 (3): 233-258.

Mueller, C. 2012. Secession and Self-determination - Remedial Right Only Theory Scrutinised. POLIS Journal 7 (2): 283-321. 
Nwabueze, B. 2003. Towards a Wider Understanding of Inter-Group Relations. In Akinyele, R.T . (ed.), Race, Ethnicity and Nation-Building in Africa. Enugu: Rex Charles Publication.

Ogundiya, I. S. 2009. The Cycle of Legitimacy Crisis in Nigeria: A Theoretical Exploration. Journal of Social Science 20 (2): 129-142.

Okoli, A., Erunke, J., Igata, F., and Nwaiwu, Ch. 2015. Biafra Republic will be declared without bloodbath - MASSOB. Vanguard. November 16. URL: https://www.vanguardngr.com/2015/11/massob-blasts-fr-mbakaover-anti-biafra-stance/. Accessed July 19, 2017.

Onyeonoro, S. K. 1973. Discontinuities in Political Socialisation in Nigeria. Political Science 25 (2): 86-102.

Rifai, K. E., and Slotine, J. J. E. 2006. Compositional Contraction Analysis of Resetting Hybrid Systems. In IEEE Transactions on Automatic Control 51 (9): 1536-1541. URL: http://ieeexplore.ieee.org/document/1695998/? section $=$ abstract.

The Constitution of the Federation of Nigeria, 1960. URL: https://en.wiki source.org $/$ w/index.php?title $=$ Special:ElectronPdf\&page $=$ Constitution + of + Nigeria $+\% 281960 \% 29$ \&action=show-download-screen. Accessed October 8, 2017.

The National Conference, 2014. Final Draft Report. August, 2014. URL: http://thewillnigeria.com/news/wp-content/uploads/2014/08/1.pdf. Accessed January 15, 2017.

Nigeria, Constitutional Conference. 1995. Report of the Constitutional Conference, Abuja, Nigeria.

The United Nations Charter. 1945. Charter of the United Nations and the Statute of the International Court of Justice. URL: https://treaties.un.org/ doc/publication/ctc/uncharter.pdf. Accessed: November 3, 2017.

United Nations General Assembly. 1970. Declaration on Principles of International Law concerning friendly relations and cooperation among states in accordance with the charter of the United Nations, 24 October. URL: http://daccessddsny.un.org/doc/RESOLUTION/GEN/NR0/348/90/IMG/ NR034890.pdf?OpenElement Accessed: February 26, 2012.

United Nations. 1976. International Covenant on Civil and Political Rights. URL: http://treaties.un.org/doc/Publication/UNTS/Volume\%20999/volu me-999-I-14668English.pdf. Accessed February 2, 2012.

United Nations. 1997. International Covenant on Economic, Social and Cultural Rights. URL: http://www.hrweb.org/legal/escr.html. Accessed February $20,2012$.

United Nations. 2012a. Charter of the United Nations. URL: http://www.un.org/ en/documents/charter/index.shtml. Accessed February 26, 2012.

United Nations. 2012b. Committee of 24 (Special Committee on Decolonisation). URL: http://www.un.org/en/decolonization/specialcommittee.shtml. Accessed April 4, 2012. 
Universal Declaration of Human Rights, 1948. URL: http://www.un.org/ en/universal-declaration-human-rights/index.html. Accessed February 17, 2017.

Wang, W., and Slotine, J. J. E. 2004. Where to Go and How to Go: A Theoretical Study of Different Leader Roles. NSL Report 040202. Cambridge, MA: MIT.

Wheare, K. C. 1946. Federal Government. London: Oxford University Press.

Whitaker, C. S. Jr. 1981. Second Beginnings: The New Political Framework. A Journal of Opinion 11 (1): 2-12. 